\title{
Adenoid Cystic Carcinoma in the Cavernous Sinus Diagnosed with the Endoscopic Endonasal Approach
}

\author{
Endoskopik Endonazal Yaklaşımla Tanı Alan Kavernöz Sinüs Adenoid \\ Kistik Karsinomu
}

Yasuhiko HAYASHI ${ }^{1}$, Masayuki IWATO ${ }^{1}$, Daisuke KITA ${ }^{1}$, Katsuyoshi MIYASHITA ${ }^{1}$, Tomokazu YOSHIZAKI ${ }^{2}$, Jun-ichiro HAMADA ${ }^{1}$

${ }^{1}$ Kanazawa University, Graduate School of Medical Science, Department of Neurosurgery, Kanazawa, Ishikawa, Japan

${ }^{2}$ Kanazawa University, Graduate School of Medical Science, Department of Otolaryngology, Kanazawa, Ishikawa, Japan

Corresponding Author: Yasuhiko HAYASHI / E-mail: yahayashi@med.kanazawa-u.ac.jp

\begin{abstract}
A 42-year-old woman presented with right oculomotor, abducens, and trigeminal palsy. Neuroimaging revealed a small lesion in the right cavernous sinus mimicking meningioma. Because the symptoms gradually worsened, the patient underwent an endoscopic endonasal transsphenoidal surgery for tumor biopsy. Histological examination of the surgical specimen revealed adenoid cystic carcinoma (ACC). Before and after the operation, no evidence of other primary lesions could be detected. The patient was treated with stereotactic radiosurgery (SRS). ACC in the cavernous sinus can be difficult to diagnosis before histological confirmation, because it is extremely rare as a primary lesion and resembles a cavernous sinus meningioma on neuroimaging studies. Two years after the first SRS, the tumor recurred along the trigeminal nerve and SRS was performed again. Our study illustrates that in case in which a lesion in the cavernous sinus progresses on neurological and neuroimaging studies, a biopsy should be taken to provide most accurate diagnosis and treatment.
\end{abstract}

KEYWORDS: Adenoid cystic carcinoma, Cavernous sinus, Endonasal approach, Endoscope, Radiosurgery

öz

42 yaşındaki bir kadın sağ okülomotor, abdusens ve trigeminal sinir paralizileri ile başvurdu. Nörogörüntüleme sağ kavernöz sinüste menenjiyomu taklit eden küçük bir lezyon saptadı. Belirtiler yavaş yavaş kötüleştiği için, hastaya tümör biyopsisi için endoskopik endonazal transsfenoidal cerrahi uygulandı. Cerrahi örneğin histolojik incelemesinde adenoid kistik karsinom (ACC) saptandı. Operasyon öncesi ve sonrasında başka bir primer lezyon bulgusu saptanmadı. Hasta stereotaktik radyocerrahi (SRS) ile tedavi edildi. Bir primer lezyon olarak son derece nadir görüldüğü ve beyin görüntüleme çalışmalarında kavernöz sinüs menenjiyomuna benzediği için kavernöz sinüsteki ACC'un tanısını histolojik teyitten önce koymak zor olabilir. Illk SRS'den iki yıl sonra tümör trigeminal sinir boyunca tekrarladı ve yeniden SRS uygulandı. Çalışmamız nörolojik ve beyin görüntüleme çalışmalarında bir lezyonun kavernöz sinüste ilerlediği olgularda en doğru tanı ve tedaviyi sağlamak için biyopsinin alınması gerektiğini göstermektedir.

ANAHTAR SÖZCÜKLER: Adenoid kistik karsinom, Kavernöz sinüs, Endonazal yaklaşım, Endoskopi, Radyocerrahi

ABBREVIATIONS: ACC, adenoid cystic carcinoma; MRI, magnetic resonance imaging; SRS, stereotactic radiation surgery

\section{INTRODUCTION}

Adenoid cystic carcinomas (ACCS) are rare, malignant, epithelial tumors in the oral and maxillofacial regions. These areas include the major and minor salivary glands, nasopharynx, lacrimal glands, upper respiratory tract, lung, mammary gland, skin, mastoid air cell, and genital tract. ACCs make up about $1 \%$ of epithelial tumors in these regions and occur most commonly among women in the 5th and 6th decades of life $(6,24)$. This type of tumor is slow growing, but is highly invasive and is associated with a high recurrence rate $(6,11)$.

Intracranial ACC develops infrequently and could result from direct invasion from the skull base, as well as from hematogenous or perineural spreading. The incidence of intracranial invasion varies from $4 \%$ to $22 \%$, and the most popular routes are reported to be the optic chiasm and the Gasserian ganglion $(4,9,17,24)$.

We report a case of ACC located only in the cavernous sinus without evidence of other primary lesions. The neuroimaging study indicated a likely meningioma in the cavernous sinus, but a specimen obtained by successful endoscopic endonasal biopsy confirmed ACC as the histological diagnosis.

\section{CASE REPORT}

A 42-year-old woman who had facial numbness, photophobia, diplopia, and ocular pain presented at a local hospital. Neurological examination revealed restricted eyeball movement, pupil with dilatation and incomplete reaction for 
light, and ptosis of the right side, suggesting the involvement of the $3^{\text {rd }}, 4^{\text {th }}, 5^{\text {th }}(\mathrm{V} 1>V 2)$, and $6^{\text {th }}$ cranial nerves. Magnetic resonance imaging (MRI) showed a mass lesion in the right cavernous sinus. Her past medical history was unremarkable, and the laboratory findings were within normal range. She was transferred to the department of neurology in our hospital for further examination. The MRI performed in our hospital was consistent with her previous assessment showing a mass lesion in the cavernous sinus.

Computed tomography revealed a 2-cm diameter mass lesion with slightly high density in the right cavernous sinus. MRI revealed a homogenous and isointense mass contained entirely within the right cavernous sinus both on T1- and T2weighted images (Figure 1A, B), with a heterogenous and well-enhanced character (Figure 1C). Dynamic study on the T1-weighted coronal section displayed as early filling of the contrast agent, gadolinium, in the normal pituitary gland (Figure 1D). The patient was referred to our department and admitted for biopsy of the lesion without enlargement of the mass on MRI compared with previous image obtained 1 year before. Although the gallium scintigraphy study was negative, thallium citrate scintigraphy revealed positive accumulation at the right cavernous sinus, with a delayed (but not early) image (Figure 1E,F). Both kinds of scintigraphies displayed no other hot spot in any other region of the body. Together, these findings point to a diagnosis of meningioma in the cavernous sinus, but a surgical biopsy using an endoscopic endonasal transsphenoidal approach was performed in order to ensure an accurate diagnosis.

The target point for tumor biopsy was localized in the anteroinferior portion of the cavernous sinus. The lower half of the middle turbinate and the posterior nasal septum were removed, and the anterior wall of the sphenoid sinus was widely opened by enlarging the right sphenoid sinus ostium laterally. The rigid endoscope was advanced straight forward to the target point of the cavernous sinus after taking down the intrasinus septum. The dura mater was opened anteroinferior to the internal carotid artery under the navigation guidance. Biopsies were performed at the subdural intracavernous space in the cavernous sinus. The tumor was slightly firm and bled easily, but intraoperative hemostasis was achieved with fibrin glue and Surgicel (Ethicon, Somerville, NJ; Figure 2A,B).

Histological examination showed that the tumor cells had a cribriform pattern with infiltration into the fibrous tissue and no intervening neural or glial tissue with invasion of tumor cells along the peripheral nerve, suggesting ACC (Figure 3).

The postoperative course was uneventful, and the patient later received stereotactic radiosurgery (SRS, total $36 \mathrm{~Gy}$ ) for the tumor in the cavernous sinus. After this SRS, her neurological deficits did not improve remarkably despite moderate tumor
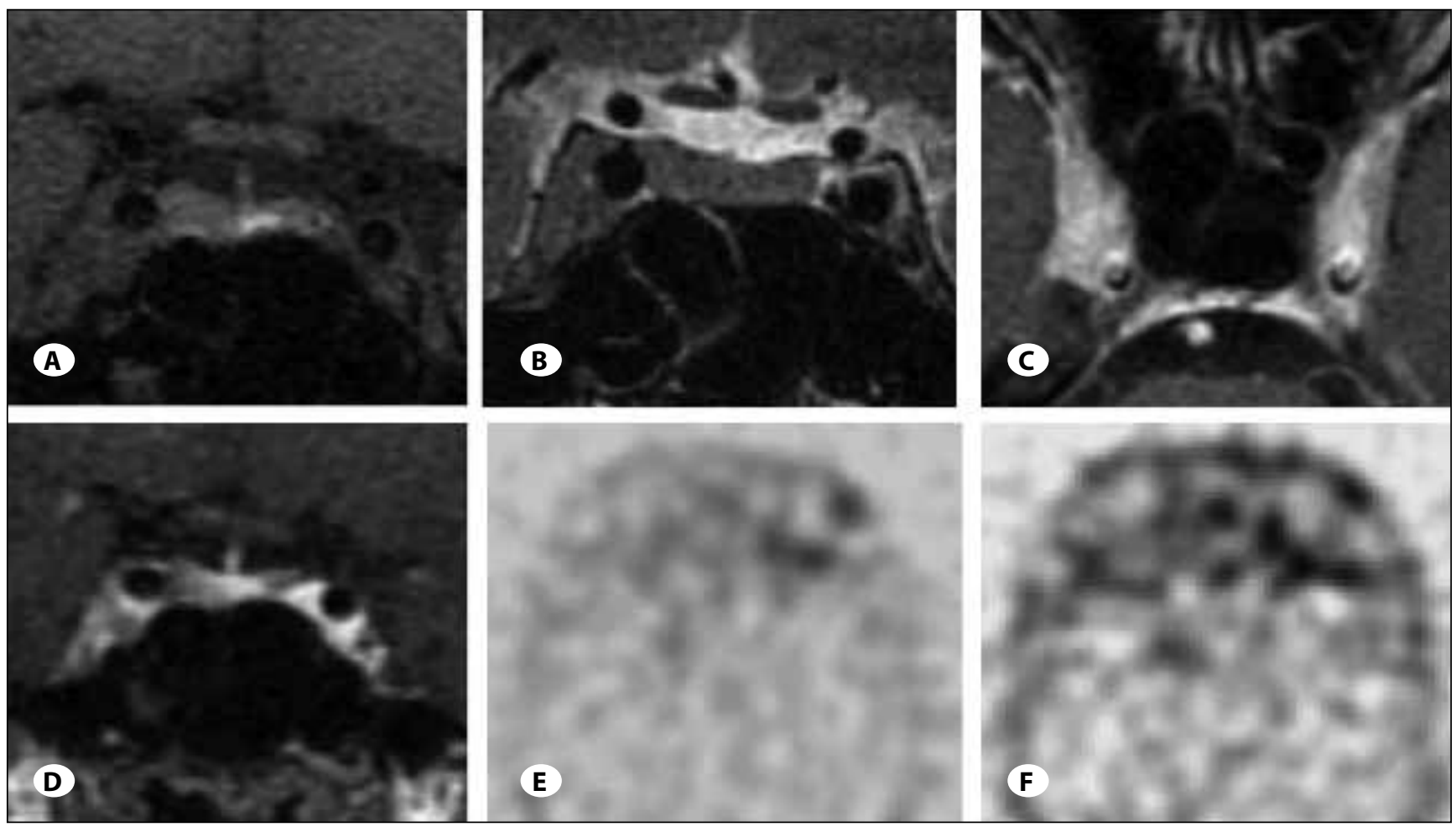

Figure 1: A, B) Magnetic resonance imaging revealed that the right cavernous sinus was entirely filled with a homogenous and isointense mass both on the coronal section of T1- and T2-weighted images $\mathbf{C}$ ) with heterogenous and strongly enhanced manner on the axial section of T1-weighted image. D) Dynamic study of the T1-weighted coronal section of MRI displayed as early filling of contrast agent, gadolinium, as the normal pituitary gland. E) 201Thallium citrate scintigraphy of the head revealed positive accumulation only at the right cavernous sinus, which appeared faintly in the early image but F) strongly in the delayed one. 

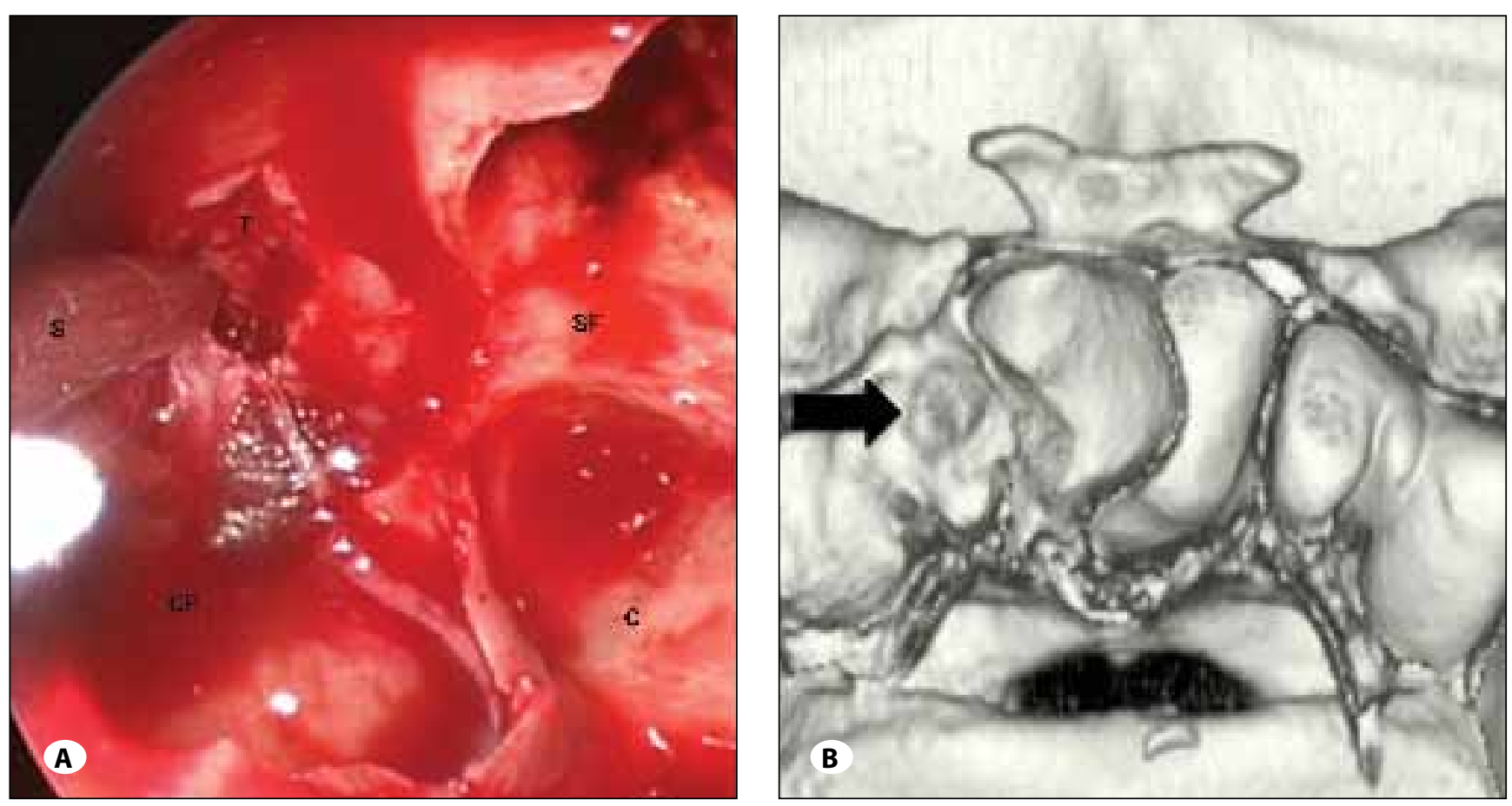

Figure 2: A) The rigid endoscope was advanced directly to the target point of tumor biopsy under the observation of the navigation. The dura mater of the carotid prominence was incised to expose the tumor inside the cavernous sinus. C; clivus, CP; carotid prominence, $\mathrm{S}$; suction, SF; sellar floor, T; tumor. B) Postoperative three-dimensional computed tomography scan clearly revealed the bony removal of the right carotid prominence in front of the tumor (arrow).

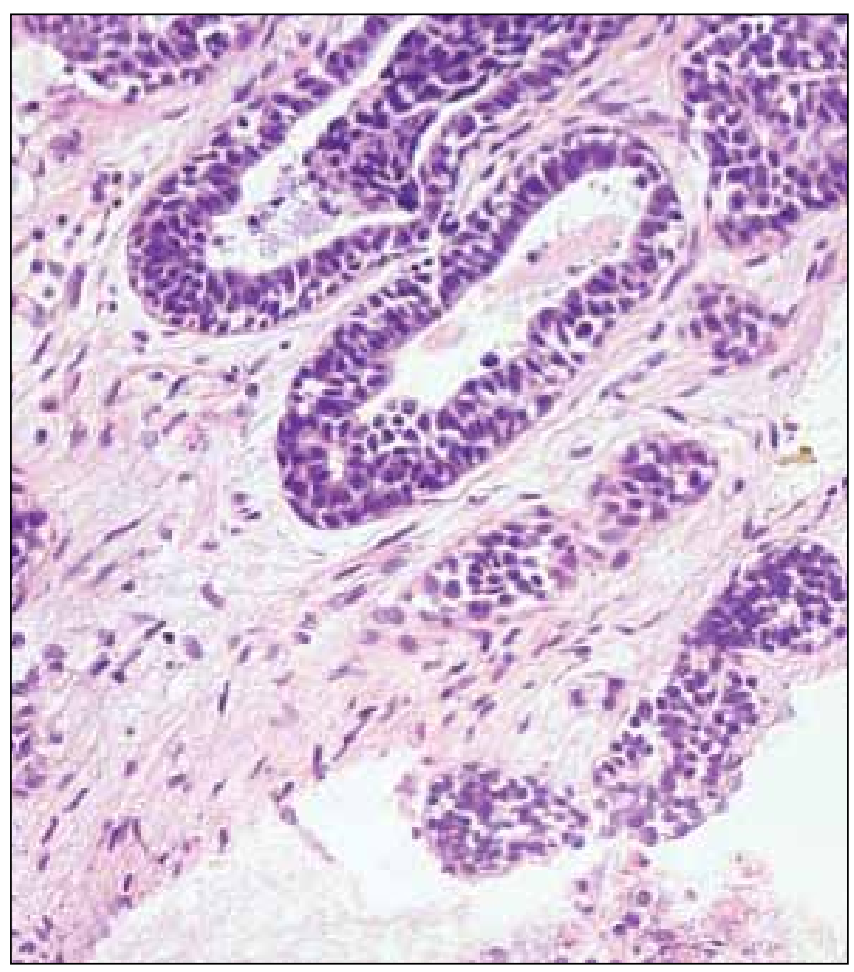

Figure 3: The pathological examination of the surgical specimen indicated that the tumor cells had a cribriform pattern with infiltration into the fibrous tissue and no intervening neural or glial tissue suggesting adenoid cystic carcinoma (hematoxylin and eosin, x100). reduction. However, this may be due in part to the fact that her facial numbness had been gradually deteriorating for 2 years prior to surgery. MRI revealed tumor infiltration along the right trigeminal nerve through the foramen rotundum and ovale, although no other lesion could be detected intracranially and extracranially. Therefore, additional SRS (total $30 \mathrm{~Gy}$ ) was performed along the perineural infiltration. No neurological deterioration and tumor regrowth appeared within the first 2 years after the second SRS.

\section{DISCUSSION}

The only 2 cases of ACC in the cavernous region that are considered to be a primary or solo intracranial lesion have been reported to date. Piepmeier et al. reported a 38-yearold male presented with total ophthalmoplegia, facial hypesthesia in the territory of the trigeminal nerve, and visual acuity loss. Although neuroradiological examination was performed only with computed tomography scan, this brain tumor extended into the orbit and was considered to originate from the right cavernous sinus. The patient underwent a right frontotemporal craniotomy for a biopsy that confirmed the presence of an invasive ACC, and subsequently was treated with radiation therapy (17). Adachi et al. reported the case of a 62-year-old male who suffered from a lesion at the cavernous sinus and Meckel's cave causing right oculomotor, abducens, and trigeminal nerve disturbance. The patient underwent $a$ right temporal craniotomy for gross total resection revealed an ACC. After the operation, no evidence of the primary lesion could be found and fractionated radiation of the lesion was performed (2). 
As described above, ACC is a malignant epithelial neoplasm and derives from the exocrine glands, such as the salivary and lacrimal glands, and nasopharynx $(6,8)$. However, there are no reports concerning how the abnormalities in the exocrine glands originated from or migrated into the cavernous sinus. Therefore, the origin of how ACC develops from the cavernous sinus (as was observed in our case) remains unknown. The possibility of metastasis into the cavernous sinus remains controversial because no lesions other than that in the cavernous sinus have been detected on neuroradiological imaging.

Surgery for lesions in the cavernous sinus has always been a surgical challenge because of the high functional importance of this region and the associated high morbidity (10). However, the recent advances in endoscope technology allows for adequate exposure of this region with a reduction in surgical morbidity (7). The usefulness of the endoscope for this region should be stressed. The anterior portion of the cavernous sinus could be exposed by removal the lower part of the middle turbinate and the posterior ethmoidal cells $(1,3)$. The introduction of the endoscope 30 degrees from the contralateral nostril can provide a wide view for the medial wall of the cavernous sinus (1).The technique is safe, effective, and accurate for biopsy and provides a way to manage lesions at the cavernous sinus $(12,18)$. Sung et al. reported a case of transnasal endoscopic surgery for a metastatic ACC of the cavernous sinus, and they stressed that this approach is a safe and efficacious method to obtain tissue specimens of this lesion (21). Their procedure is almost the same as ours.

In our case, it was difficult to rule out the diagnosis of meningioma in the cavernous sinus. The MRI findings were compatible to the ones of meningioma, such as isointensity of the T1-weighted image, slight hyperintensity of the T2weighted image, marked enhancement of entire tumor, and delayed increase of the thallium accumulation (5). Sugo et al. suggested the early image of 201-TI dynamic scintigraphy is useful for distinguishing malignant brain tumors from benign tumors (20). Although the number of the reported cases about TI-scintigraphy of ACC is still small, some authors noted that ACC, as well as other malignant tumors, show increased uptake. The increased uptake is especially evident in the early phase, which is significantly correlated to the grade of malignancy, such as the MIB1 labeling index $(16,20,22)$.

The optimal treatment for ACC is radical surgical resection, but this intervention remains untenable because this tumor has a characteristic perineural invasive character. Although some authors reported the efficacy of radiotherapy for ACC as adjuvant therapy, no definitive conclusions have been drawn because of the small number cases reported. Miller reported that although most ACCs recur within the first 3 years, the palliation of symptoms could be accomplished in the majority of cases (14). Mori addressed in selected patients with recurrent skull base ACC, SRS can be considered effective as a salvage treatment (15). In our case, 2 SRS treatments were performed resulting in local control for 4 years. Even if ACC would be controlled locally, distal metastasis could occur in as many as $39 \%$ of cases $(2,23)$.

The prognosis of ACC remains poor with as much as $70 \%$ of local recurrence rate treated by postoperative radiation $(13,19)$, but surgical excision with postoperative radiation improved the survival rate up to $80 \%$ (2). Therefore, accurate and rapid diagnosis, the largest possible tumor resection, and postoperative radiation could provide good local control and long-term survival of patients with ACC.

\section{REFERENCES}

1. Abuzayed B, Tanriover N, Gazioglu N, Ozlen F, Cetin G, Akar Z: Endoscopic anatomy and approaches of the cavernous sinus: Cadaver study. Surg Radiol Anat 32: 499-508, 2010

2. Adachi K, Yoshida K, Ueda R, Kawase T: Adenoid cystic carcinoma of the cavernous region. Neurol Med Chir (Tokyo) 46: 358-360, 2006

3. Alfieri A, Jho HD: Endoscopic endonasal approaches to the cavernous sinus: Surgical approaches. Neurosurgery 49: 354360, 2001

4. Alleyne $\mathrm{CH}$, Bakay RA, Costigan D, Thomas B, Joseph GJ: Intracranial adenoid cystic carcinoma: A case report and review of the literature. Surg Neurol 45: 265-271, 1996

5. Arsene D, Ardeleanu C, Danaila L: Skull base tumor invading both cavernous sinuses. Adenoid cystic carcinoma mimicking a meningioma. Rom J Morphol Embryol 47:367-371, 2006

6. Ferrazzo KL, Schneider PP, Shinohara EH: An unusual case of adenoid cystic carcinoma with hard palate perforation. Minerva Stomatol 60: 83-86, 2011

7. Frank G, Pasquini E: Endoscopic endonasal cavernous sinus surgery with special reference to pituitary adenomas. Front Horm Res 34: 64-82, 2006

8. Gondivkar SM, Gadbail AR, Chole R, Panikh RV: Adenoid cystic carcinoma: A rare clinical entity and literature review. Oral Oncol 47: 231-236, 2011

9. Gormley WB, Sekhar LN, Wright DC, Olding M, Janecka $\mathrm{IP}$, Snyderman $\mathrm{CH}$, Richardson R: Management and longterm outcome of adenocystic carcinoma with intracranial extension: A neurosurgical perspective. Neurosurgery 38(6):1105-1112; discussion 1112-3, 1996

10. Inose $Y$, Kobayashi M, Hiroi A, Toi S, Maruyama K, Shimizu Y, Shibata N, Yoshihara T, Uchiyama S: A case of adenoid cystic carcinoma presenting as Garcin's syndrome without mass formation. Intern Med 51: 87-91, 2012

11. Jayalakshim S, Agarwall S, Nachiappan PL, Prasad RR, Bhuthra S, Sharma MC, Julka PK: Intracranial adenoid cystic carcinoma. J Neuro-Oncology 47: 47-50, 2000

12. Liu HS, Di X: Endoscopic endonasal surgery for biopsy of cavernous sinus lesions. Minim Invasive Neurosurg 52: 69-73, 2009

13. Meldrum MI, Tse DT, Benedetto P: Neoadjuvant intracarotid chemotherapy for treatment of advanced adenocystic carcinoma of the lacrimal gland. Arch Ophthalmol 116: $315-321,1998$ 
14. Miller RC, Foote RL, Coffey RJ, Gorman DA, Earle JD, Schomberg PJ, Kline RW: The role of sterotactic radiosurgery in the treatment of malignant skull base tumors. Int J Radiat Oncol Biol Phys 39: 977-981, 1997

15. Mori Y, Kobayashi T, Kida Y, Oda K, Shibamoto Y, Yoshida J: Stereotactic radiosurgery as a salvage treatment with good local control. Stereotactic Functi Neurosurg 83: 202-207, 2005

16. Nose H, Tsuboi K, Hommura S, Ishikawa N: Thallium-201 SPECT of orbital tumors. Orbit 18: 261-266, 1999

17. Piepmeier JM, Virapongse C, Kier EL, Kim J, Greenberg A: Intracranial adenoid cystic carcinoma presenting as a primary brain tumor. Neurosurgery 12: 348-352, 1983

18. Saeki N, Horiguchi $K$, Murai $H$, Hasegawa $Y$, Hanazawa $T$, Okamoto Y: Endoscopic endonasal pituitary and skull base surgery. Neurol Med Chir (Tokyo) 50: 756-764, 2010

19. Selcuk A, Dere H, Bahar S, Sarikaya Y, Ozcan M: Adenoid cystic carcinoma of the parotid gland presenting as temporal bone neoplasm: A case report. B-ENT 3: 163-166, 2007
20. Sugo N, Yokota K, Kondo K, Harada N, Aoki Y, Miyazaki C, Nemoto M, Kano T, Ohishi H, Seiki Y: Early dynamic 201-TI SPECT in the evaluation of brain tumors. Nucl Med Commun 27: 143-149, 2006

21. Sung A, Bergsneider $M$, Wang M: Transnasal endoscopic surgery of the cavernous sinus for tissue diagnosis. The Laryngoscope 120: 282-284, 2010

22. Takeda T, Nakano T, Asano K, Shimamura N, Ohkuma H: Usefulness of thallium-201 SPECT in the evaluation of tumor natures in intracranial meningiomas. Neuroradiology 53: 867-873, 2011

23. Terasaki $M$, Tokutomi $T$, Maruiwa $H$, Sugita $Y$, Harada $H$, Shigemori $M$ : High-grade adenoid cystic carcinoma originating from the lacrimal gland. Brain Tumor Pathol 17: 159-163, 2000

24. Wakisaka S, Nonaka A, Morita Y: Adenoid cystic carcinoma with intracranial extension: Report of three cases. Neurosurg 26: 1060-1065, 1990 